\title{
Leaders' Communication Ethics in The Innovation Diffusion Process at School System: Investigated from Balinese Philosophy of Life
}

\author{
Luh Putu Putrini Mahadewi1,2*, Suyitno Muslim², I Made Tegeh1, Ida Bagus Made \\ Astawa $^{3}$ \\ ${ }^{1}$ Program Studi Teknologi Pendidikan, Universitas Pendidikan Ganesha, Singaraja, Indonesia \\ ${ }^{2}$ Program Pascasarjana Prodi Teknologi Pendidikan (S3), Universitas Negeri Jakarta \\ ${ }^{3}$ Program Studi Pendidikan Geografi, Universitas Pendidikan Ganesha
}

\section{ART ICLE INF O}

\section{Article history:}

Received September 26, 2021

Revised September 28, 2021

Accepted October 30, 2021

Available online December 25, 2021

Kata Kunci:

Difusi Inovasi, Etika Berkomunikasi, Filosofi

\section{Keywords}

Innovation Diffusion, Communication Ethics, Philosophy

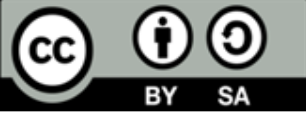

This is an open access article under the CC BY-SA license.

Copyright $(\subseteq 2021$ by Author. Published by Universitas Pendidikan Ganesha.

\begin{abstract}
A B S T R A K
Elemen penting difusi inovasi salah satunya adalah saluran komunikasi. Setiap saluran komunikasi memiliki etika dan strategi komunikasinya masing-masing dalam upaya memengaruhi anggota suatu sistem sosial tertentu dalam mengadopsi tidaknya suatu inovasi. Penelitian ini bertujuan untuk menganalisis urgensi peran etika berkomunikasi pimpinan dalam proses difusi inovasi pembelajaran digital dilihat dari filosofi hidup anggota sistem sosial tempat difusi inovasi terjadi. Metode penelitian yang digunakan adalah metode penelitian deskriptif (cross-sectional study) dengan menggunakan metode survey. Hasil analisis menunjukkan bahwa peran etika berkomunikasi dalam proses difusi inovasi pembelajaran digital pada sistem persekolahan sangat urgen pada aspek-aspek: pihak yang wenang mengkomunikasikan, komunikasi interpersonal para pimpinan yang simetris, dan penghargaan terhadap lingkungan dan masyarakat melalui pendekatan konflik kepentingan, dan tanggung jawab sosial. Dapat disimpulkan bahwa ditinjau dari filosofi hidup masyarakat Bali, etika komunikasi pimpinan dalam proses difusi inovasi pada sistem persekolahan sangat nampak pada aspek penghargaan terhadap lingkungan yakni pendekatan konflik kepentingan difusi inovasi. Tulisan awal ini masih perlu disempurnakan dengan data empiris lebih lanjut di lapangan, sehingga dapat memberikan gambaran menyeluruh keterkaitan difusi inovasi dengan faktor-faktor yang potensial memengaruhi diadopsi tidaknya inovasi pada satu atau lebih sistem sosial persekolahan lainnya.
\end{abstract}

\begin{abstract}
A B S T R A C T
The most important element of innovation diffusion is communication. Each communication pathway has its ethics and specific social system in adopting innovations. This research aimed at analyzing the urgency of the leader's communication ethic roles on the process of innovation diffusion in digital learning investigated from Balinese philosophy of the social life where the innovation diffusion happened. The research method used was descriptive research (cross-sectional study) with a survey as the instrument of collecting the data. The data analysis shows that the ethical roles of communication in innovation diffusion of digital learning on the school system are urgently investigated several aspects, such as: authorized party to communicate, interpersonal communication of symmetric leadership, and rewards for the environment and society through conflict interest approach and social responsibility. In a nutshell, investigated from Balinese philosophy perspective, leadership communication roles inside of the innovation diffusion on the school system are clearly shown on the reward aspect towards the environment which is conflict interest innovation diffusion approach. This writing still needs improvements in the aspect of further empirical data on the field thus can give the whole pictures related to innovations diffusion with and the potentials influencing factors in adopting innovations on one or more social systems of other schools.
\end{abstract}




\section{INTRODUCTION}

Digital technology development has an impact on any aspect of social life in the Industrial Revolution 4.0, moreover in the education field. Digital learning is one of the most reasonable things in the education world and the traditional model of education is fully irreplaceable (Falloon, 2020; Nugroho et al., 2021; Qureshi et al., 2021). This has its effect on teachers finding new ways in improving the learning process in the future through varied innovations in education (Qureshi et al., 2021; Ross, 2020; P. Sharma, 2019). Diffusion is a social process that appeared between people in responding to innovation. Innovation diffusion is related to dissemination and implementation, continuity, and activity improvisation. Everett M. Rogers as an innovation diffusion expert defines it as a process where innovation is communicated through one specific way at one time in certain social system. There are four elements of innovation diffusion, such as the innovation itself, communication channel, time, and social system (Dearing \& Cox, 2018; Weigel et al., 2014). The adoption of varied digital learning needs policies which can guide innovation diffusion for an education institution, especially in the teachers learning in the related institution (Dubé \& Dubé, 2021; Gogus, 2021). The policy communication by the leaders of school institution to the social member system in the institution itself becomes an important aspect in innovation diffusion. The research of innovation diffusion in the education field which is published shows that the innovation diffusion of digital learning especially in the school system has not been investigated yet. The innovation adoption through procurement technology products in the education field by the agencies still needs a need analysis and the presence of information sources to get information related to the innovation itself (Morrison et al., 2019; Kintu et al., 2017; Mardiana, 2020). Even though the social influence gotten by the adopter (innovation adopter) through communication and communication ways carried out to obtain the innovation acceptance in the technology field. Compared to the mass media, interpersonal communication creates a higher proportion towards knowledge expertise and innovation use (Dosaya et al., 2020; Friedrichsen et al., 2017).

Interpersonal communication of institution leaders in delivering innovation diffusion policies with the staff is a social influence of leaders' opinions related to innovation diffusion in the new technology. Interpersonal communication influences elements of the leaders cannot be separated from the communication ethic aspect thus the innovation can be accepted by the social system members in the related institution. The ethics of leaders in communicating an innovation will shape the organizational culture and culture of innovation effectiveness and increase the readiness of staff in the organization to adopt the innovation (Atkin et al., 2015; Metwally et al., 2019). The innovation adoption in the digital learning field is a product of information, communication, and technology influenced by local cultural values adopted by the relevant social system. Even the integration of digital technology in learning related to the inheritance of cultural values in different contexts shows an increase. This shows a close relationship between how technology innovation is diffused and how technology itself is ultimately used for the preservation of cultural values in their respective contexts (Arteaga et al., 2021; Huang et al., 2021). The Laboratorium School of Universitas Pendidikan Ganesha (Lab School) is located in North Bali as the only agency of Teacher Training Institute that works under the Universitas Pendidikan Ganesha. The school becomes a reference to other schools to adopt varied innovations in learning. As one of the social systems, Lab School is part of a foundation. There are four levels of schools that are sheltered in this foundation, starting from the Early Childhood Education, Elementary School, Primary School, and High School led by respective headmasters/es. Operationally speaking, the headmasters are responsible directly to the director and the vice director which are the members of Laboratorium School of Universitas Pendidikan Ganesha direction. The director and vice-director are responsible directly towards the head of the foundation. One of the philosophic values in the local environment (Balinese Society) that is Tri Hita Karana becomes a strong foundation of the school is running its missions including its innovation adoption program. This philosophical value is in line with the values that are the philosophy of the Universitas Pendidikan Ganesha.

The diffusion of digital learning innovations in the Lab School has started in 2011 and has been increased massively in 2020 until now. However, until now, there has not been an analysis of how the innovation communication process is carried out, particularly the analysis of the role of ethics in the communication of leaders associated with the context of the life view/philosophy of the community where the Lab School is located, namely Tri Hita Karana. This is important considering that the school as a social system is closely related to the social influence of the parties involved, especially the leaders, in the social processes within the social system that has an impact on whether or not innovation is adopted. Tri Hita Karana as three forms of a harmonious relationship between humans and God (parhyangan), humans with fellow humans (pawongan), and humans with the environment (palemahan) is one of the philosophical values of Balinese society that underlies the procedures for actions (ethics) of the Balinese people in 
maintaining harmony (Kusumayani, 2019; Weda et al., 2016; Yunita \& Tristiantari, 2019). The essential elements of innovation diffusion, namely communication and social systems, are reflected in the existence of pawongan. The relationship between humans and humans (pawongan) emphasizes the development of emotional intelligence to create harmony within the organization (Sedana Suci et al., 2018; Sukarma, 2016).

The leader of any agency or institution, including education, greatly influences the organizational culture. It is the leader who promotes and imitates the principles and values by the vision, mission, and goals of the agency/institution/organization to the staff. Value systems and ethics have become a priority for 21st-century organizations. There are internal tasks and practices as well as external factors that organizational leaders must pay attention to. Internal tasks and practices are to harmonize the vision, mission, goals, strategies to achieve goals, and the organization's own culture. External factors provide opportunities and threats, such as following technological advances, globalization, and the threat of competition. Although the role of a leader is very complex, it is still necessary to integrate ethical practices into various organizational policies. This ethical practice is closely related to symmetrical internal communication by promoting open and transparent communication, respecting relationships with the environment and society (Grigoropoulos, 2019; Men, 2015). Based on the explanation above, an analysis of the innovation communication process, especially the role of leadership communication ethics associated with the context of the life view/philosophy of the community where the social system is located, needs to be carried out to obtain an overview of the diffusion of digital learning innovations in the school system. This study aims to analyze the urgency of the leaders' communication ethics in the diffusion of innovation in the school system at the Laboratory School of the Universitas Pendidikan Ganesha in terms of the Balinese philosophy of life.

\section{METHODS}

This research is a descriptive type of cross-sectional study, that is descriptive research that involves one-time interaction with participants (Pandis, 2014; Wang \& Cheng, 2020). The participants in this study were the leaders in the social system of the Laboratory School of the Ganesha University of Education. The leaders are the Chair of the Foundation, the Director and Deputy Director, as well as the Principals of the Early Childhood Education, Elementary School, Primary and High School levels. The data collection method used was a survey. The survey is presented in the format of closed-ended questions which is complemented by the format of open-ended questions for items that require further explanation (Hyman \& Sierra, 2016). This survey focused on the process of diffusion of digital learning innovations from 2020-2021. The survey blueprint was listed in Table 1 below.

Tabel 1. Communication Ethics Survey Blueprint in the Diffusion Process of Digital Learning Innovation

\begin{tabular}{|c|c|c|c|c|}
\hline No & Aspects & Indicators & \multicolumn{2}{|c|}{$\begin{array}{l}\text { Description } \\
\end{array}$} \\
\hline 1 & $\begin{array}{l}\text { Communication } \\
\text { strategy based on the } \\
\text { vision, mission, goals } \\
\text { of the organization }\end{array}$ & $\begin{array}{l}\text { Communication flow } \\
\text { Innovation communication } \\
\text { channel/container }\end{array}$ & $\begin{array}{l}2 \text { items } \\
\text { dan } \\
\text { questions) }\end{array}$ & $\begin{array}{r}\text { closed-ended } \\
\text { open-ended }\end{array}$ \\
\hline 2 & $\begin{array}{l}\text { Symmetrical } \\
\text { leadership } \\
\text { interpersonal } \\
\text { communication }\end{array}$ & $\begin{array}{l}\text { The procedure for leadership actions } \\
\text { communicates the innovation to be } \\
\text { adopted }\end{array}$ & $\begin{array}{l}2 \text { items } \\
\text { dan } \\
\text { questions) }\end{array}$ & $\begin{array}{r}\text { (closed-ended } \\
\text { open-ended }\end{array}$ \\
\hline 3 & $\begin{array}{l}\text { Appreciate the } \\
\text { relationship with the } \\
\text { environment and } \\
\text { society }\end{array}$ & $\begin{array}{l}\text { a. Steps were taken by the leadership in } \\
\text { overcoming conflicts of interest that } \\
\text { arise during the innovation } \\
\text { communication process }\end{array}$ & $\begin{array}{l}2 \text { items } \\
\text { dan } \\
\text { questions) }\end{array}$ & $\begin{array}{r}\text { (closed-ended } \\
\text { open-ended }\end{array}$ \\
\hline & & $\begin{array}{l}\text { b. Leaders consider the consequences } \\
\text { that arise from communication during } \\
\text { the process of diffusion of innovation } \\
\text { and its sustainability for the school's } \\
\text { social system. }\end{array}$ & $\begin{array}{l}2 \text { items } \\
\text { dan } \\
\text { questions) }\end{array}$ & $\begin{array}{r}\text { (closed-ended } \\
\text { open-ended }\end{array}$ \\
\hline
\end{tabular}

Based on the blueprint, further questions are developed in the form of closed-ended questions and are equipped with open-ended questions. The instrument in the form of a survey was validated by 2 experts with a content validation level of high criteria (Gregori's analysis technique obtained the results of 
the validity of the research instrument of 0.8 ). The data collected from the survey was then analyzed. The analysis used was the descriptive analysis technique. This technique was used to inform policy, practice, and even more significant research given the availability and complexity of data in understanding educational issues (Loeb et al., 2017). The research method chosen was based on the following rationales. Descriptive research type cross-sectional study is the simplest observational study design where disclosure and results are determined at the same time. This type of research is very useful for building preliminary evidence in planning further studies in the future (Huang et al., 2021; Pandis, 2014).

\section{RESULT AND DISCUSSION}

\section{Result}

The following presents descriptive data on communication ethics in the process of digital learning innovations diffusion at the Laboratory School of the Universitas Pendidikan Ganesha. Descriptive data in this study are included: data on communication strategies, leadership interpersonal communication, communication conflict approach, and social responsibility and sustainability. This descriptive data is immediately interpreted per the intended aspect. First, the communication strategy data shows that the innovation communication flow is carried out referring to the leading authority in communicating innovation. Participants' responses in this study stated that the parties authorized to communicate an innovation where the Head of the Foundation, Director, Vice Director, Principals, School Committees, resource persons for school scientific activities, innovators themselves with the permission of the Head of the Foundation/Directors as shown in Figure 1 below.

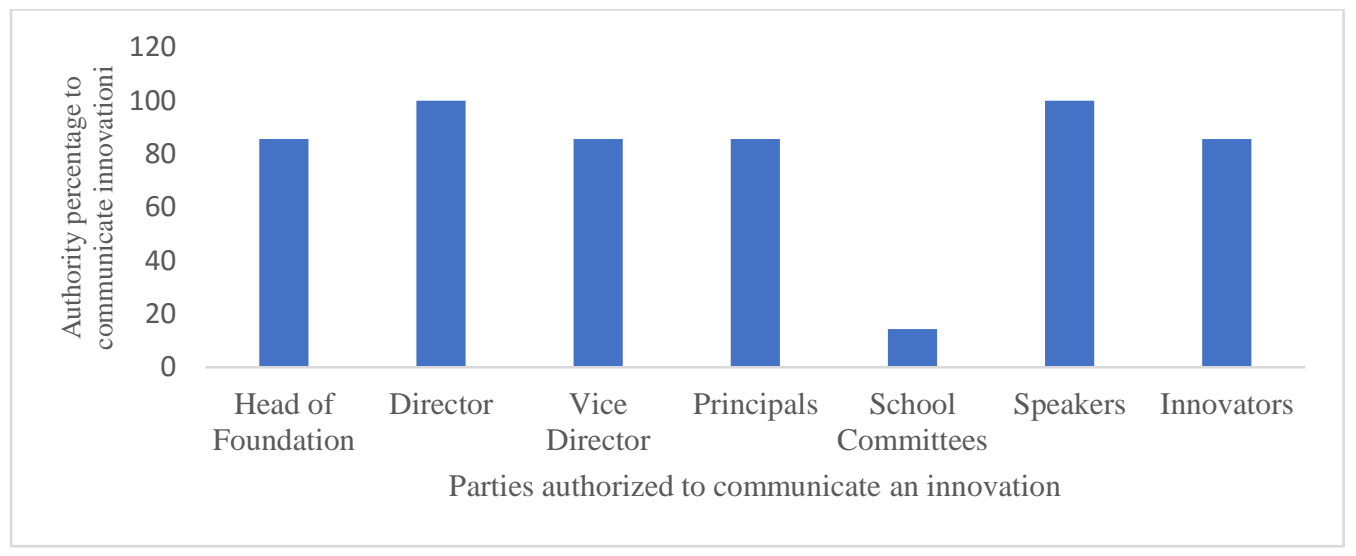

Figure 1. Innovation Communication Flow Data

The communication flow for innovation begins with the approval of the Head of the Foundation, which is forwarded to the Director and Vice Director to be further communicated to the Principal and the Principal was always the leaders at their respective levels communicating to their teaching staff. The innovation communication channels used were seminars, workshops, focus group discussions (FGD), and official school meetings. Second, leadership communication ethics. The data shows that $100 \%$ of the social system leaders of the Laboratory School of the Universitas Pendidikan Ganesha communicate an innovation ethically. The data is presented in Figure 2 below.

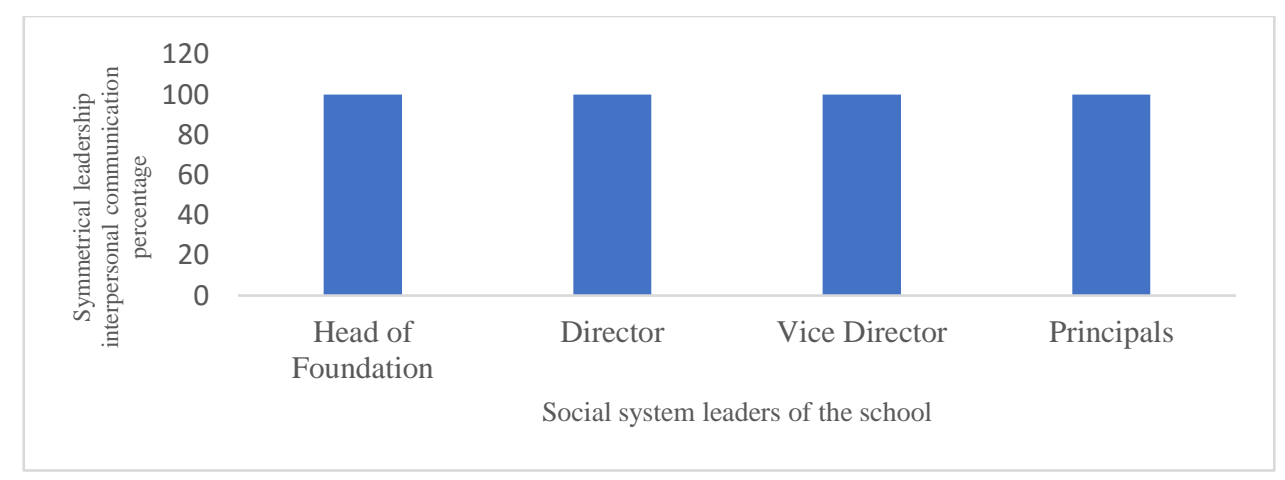

Figure 2 Innovation Communication Ethics Data by School Leaders 
Participants' responses regarding their interpersonal communication in conveying an innovation have referred to the policy guidelines for conveying an innovation. This is justified from their response to the open-ended question which confirms that through a guide to implementing an innovation's communication and interpersonal communication, innovation communication for staff runs effectively as evidenced by reporting on the implementation of scientific activities of the digital learning innovation diffusion program which is categorized as very good for two years (2020-2021). Third, leaders value relationships with the environment and society in the form of a conflict of interest and social responsibility approach. The data shows that all leaders (100\%) of the social system of the Laboratory School of the Universitas Pendidikan Ganesha approach the potential conflicts that arise in the innovation communication process. No leader ignores the conflicts that arise. All conflicts that arise try to be resolved with the best conflict approach. The data is presented in Figure 3 below.

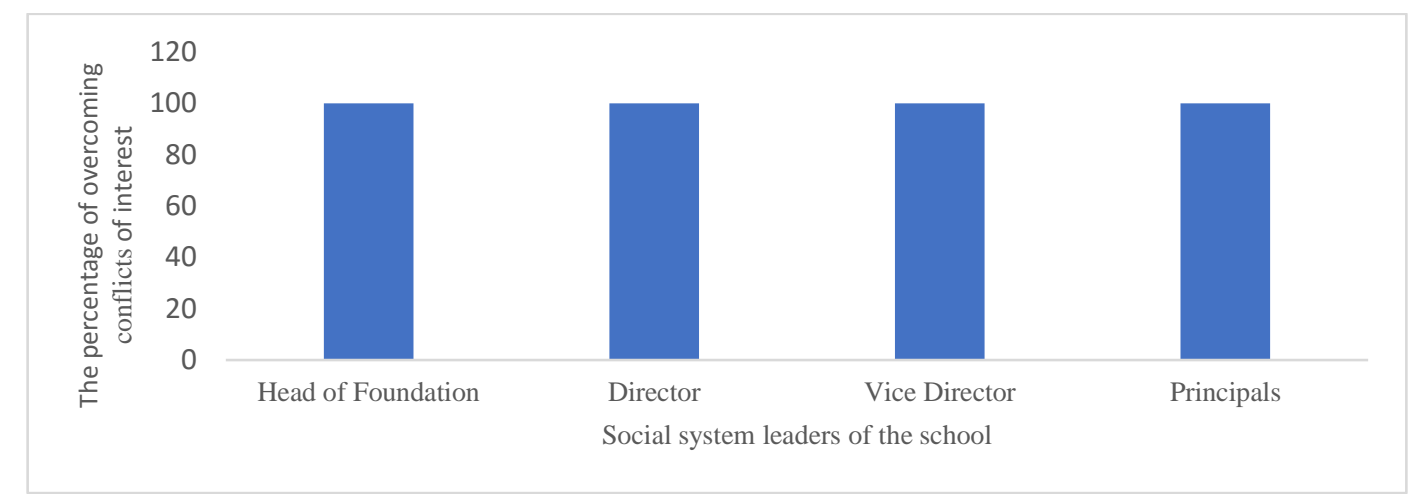

Figure 3 Data on the Implementation of the Innovation Communication Conflict Approach by School Leaders

The data from open-ended questions show that the leadership of the Laboratory School of Universitas Pendidikan Ganesha bases a conflict approach that has the potential to arise in the innovation communication process on the pawongan concept as a way of life/philosophy of Balinese society where the social system of the Laboratory School of Universitas Pendidikan Ganesha is located. Besides that, pawongan as part of the Tri Hita Karana philosophy is indeed a basic concept that animates the vision, mission, and goals of the school itself. Social responsibility data shows that all leaders (100\%) in the social system of the Laboratory School of the Universitas Pendidikan Ganesha are responsible for the messages communicated in the innovation communication process to members of the school's social system, including the consequences that arise from the adoption or not of innovation. Figure 4 shows all the leaders of the Laboratory School of Universitas Pendidikan Ganesha considering social responsibility for all messages communicated in the innovation diffusion process.

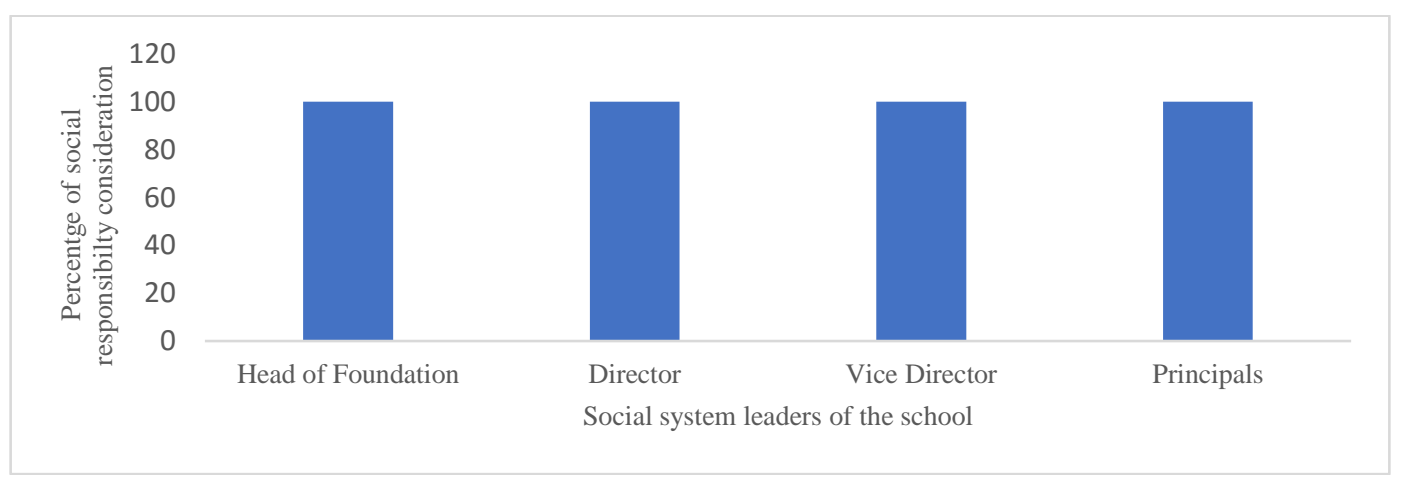

Figure 4 Data Consideration of Social Responsibility Innovation Communication by School Leaders

Through the data collected from open-ended questions, data on aspects of social responsibility are obtained which are taken into consideration in communicating an innovation. The aspects of social responsibility referred to include: aspects of teacher competence and professionalism, aspects of facilities and infrastructure, aspects of teacher welfare, aspects of school culture. 


\section{Discussion}

In general, the findings in the study indicate that communication ethics in the process of diffusion of digital learning innovations at the Laboratory School of the Universitas Pendidikan Ganesha is the main concern of leaders in communicating innovations to members of the social system, especially teachers. This is reflected in aspects of the communication strategy based on the leadership's authority, ownership of leadership interpersonal communication, respect for the environment and society in the form of a conflict approach as well as social responsibility and communication sustainability of an innovation. These three components of ethical communication practice are based on the life view/philosophy of the Balinese people which are also the cultural values of the social system of the Laboratory School of Universitas Pendidikan Ganesha. Based on the meaning of the data in the results, it can be discussed the following matters. First, the communication strategy in the diffusion of innovation is related to the communication flow that shows the authority of the leaders in communicating it. This shows that with the authority the leaders have, they can communicate innovations according to their main duties and functions ethically (Hao \& Padman, 2018; Nuswowati et al., 2017; L. Sharma \& Srivastava, 2020). However, there are still leaders who do not have the same views regarding the parties who have the authority to communicate innovations. In addition to the authority that represents the flow of communication, the communication strategy also appears in the innovation communication channels/containers that are used are various scientific activities, such as seminars, workshops, focus group discussions (FGD), and official school meetings. This is in line with research that shows that the diffusion of new technological innovations to be effectively used, in addition to the availability of technology, should be balanced with training/workshops/training for human resources users. On the other hand, the diffusion of digital learning innovations must also pay attention to the skills already possessed by school staff (Sailer et al., 2021; Winter et al., 2021).

Second, the ownership of interpersonal communication by the social system leaders of the Laboratory School of the Universitas Pendidikan Ganesha is very good. This can be seen in the responses of all leaders in the school's social system who stated that leaders communicate an innovation according to the policy guidelines owned by the school. Communication-based on these guidelines is not one-way communication but dynamic communication. This is consistent with research findings which state that dynamic communication can stimulate response and creativity to create a free and dynamic dialogue between professionals. In the end, efforts to create a common understanding of concepts in guiding the process of integrating technology ineffective learning will be realized (Grönlund et al., 2019; Tondeur et al., 2021). Third, the leaders of the Laboratory School of the Universitas Pendidikan Ganesha in carrying out the diffusion of digital learning innovations respect the environment and social system society through a conflict-of-interest approach in communication and also consider social responsibility from the content of the innovation message conveyed including the consequences of adopting or not adopting digital learning innovations. It is realized that each learning strategy with technological facilities has its advantages and disadvantages. School staff, especially teachers who are comfortable using a certain digital learning technology, have challenges in adopting a new diffusion of digital learning innovations. Especially if there are teachers who are antipathy to digital learning innovations, of course, they will be more challenged and have the potential to cause conflict in the diffusion process as an effort to update their skills to adopt digital learning. Therefore, the way the leaders approach the emerging conflicts is based on the values adopted by the social system and the existing school organizational culture, namely the pawongan concept as part of the Tri Hita Karana philosophy. This is in line with research findings which state that amid the proliferation of modern technology, Tri Hita Karana as the value of local wisdom of the Balinese people is unique in maintaining harmony. The more Tri Hita Karana is implemented properly, the more the work culture of the staff in the organization will improve (Gde et al., 2018; Suarniati, 2019).

The concept of pawongan in Tri Hita Karana emphasizes the harmonious relationship between humans and other humans. This harmony is manifested because of the development of the emotional intelligence of each individual involved in communication. Emotional intelligence plays an important role in managing emotions when dealing with conflicts, both with superiors and with subordinates. Likewise in the organization of the school system. Conflict can arise because of the attitudes, values, beliefs, and behavior of individuals who are controlled by emotions even though these individuals are involved in a social system that shares responsibility for realizing the goals of the social system itself. This finding is following the results of research showing that good emotional management through the development of emotional intelligence has a positive effect on resolving conflicts of interest in the process of diffusion of innovation in a social system including the school system (Awasthi \& Yadav, 2016; Chen et al., 2019; Kumar et al., 2018; Sukarma, 2016). Besides the conflict-of-interest approach, another aspect of respect for the environment and society concerning the ethics of innovation diffusion communication that the leaders of the Laboratory School of the Universitas Pendidikan Ganesha consider is the social 
responsibility of innovation communication, including consideration of the consequences of adopting innovations or not. The social responsibilities considered by the leaders are aspects of teacher competence and professionalism, aspects of facilities and infrastructure, aspects of teacher welfare, aspects of school culture. This is in line with the research findings, especially regarding the consideration of social responsibility on the expected performance, namely aspects of teacher competence and professionalism which have implications for the adoption of technological innovations in learning which should emphasize pedagogical practices and not business aspects of innovation (Mehta et al., 2019; Teräs et al., 2020).

As initial research on the communication aspect of the diffusion of innovation, this research certainly has limitations, including it only involves one school social system, research methods, especially on new data collection techniques, using only one tool. It is necessary to involve the opinions of members of other social systems besides leaders to obtain more holistic information, for example the teachers' decision making and practice with technology integration (Ilomäki \& Lakkala, 2018; Kopcha et al., 2020) and students' perception (Antee, 2021). In addition, the model to adopt innovation in school system needs to bedeveloped (Smith et al., 2018; Udemezue, 2018). The recommendation for further studies is to conduct more in-depth and comprehensive research on aspects related to the diffusion of learning innovations, especially those involving the cultural values of the school as an educational organization, on its elements of innovation, communication channels, time, and social system (Clausen et al., 2021; Howard et al., 2021). In addition, research can be carried out on several social systems with the cultural values of their respective organizations.

\section{CONCLUSION}

Based on the results of the analysis and discussion, it can be concluded as follows. The ethics of leadership communication in the process of diffusion of innovation in the school system are found in the aspects of authority and innovation communication programs, implementation of symmetrical leadership interpersonal communication, and respect for the environment and society. Judging from the Balinese philosophy of life, the ethics of leadership communication in the process of diffusion of innovation in the school system is very visible in the aspect of respect for the environment, namely the conflict of interest approach to the diffusion of innovation.

\section{REFERENCES}

Antee, A. (2021). Student Perceptions and Mobile Technology Adoption: Implications for Lower-Income Students Shifting to Digital. Educational Technology Research and Development, 69(1), 191-194. https://doi.org/10.1007/s11423-020-09855-5.

Arteaga, J. V., Gravini-donado, M. L., Domenico, L., \& Riva, Z. (n.d.). Digital Technologies for Heritage Teaching: Trend Analysis in New Realities. 1, 132-148.

Atkin, D. J., Hunt, D. S., \& Lin, C. A. (2015). Diffusion Theory in the New Media Environment: Toward an Integrated Technology Adoption Model. Mass Communication and Society, 18(5), 623-650. https://doi.org/10.1080/15205436.2015.1066014.

Awasthi, S., \& Yadav, P. (2016). Emotional Intelligence as a Predictor of Conflict Resolution Style in Public Sector Employees. 5(9), 21-27.

Chen, H. X., Xu, X., \& Phillips, P. (2019). Emotional Intelligence and Conflict Management Styles. International Journal of Organizational Analysis, 27(3), 458-470. https://doi.org/10.1108/IJOA11-2017-1272.

Clausen, J. M., Borthwick, A. C., \& Rutledge, D. (2021). Collaborative Research and Use of Q methodology to Understand Technology Infusion in Teacher Preparation. Educational Technology Research and Development, 69(3), 1617-1639. https://doi.org/10.1007/s11423-021-10018-3.

Dearing, J. W., \& Cox, J. G. (2018). Diffusion of Innovations Theory, Principles, and Practice. Health Affairs, 37(2), 183-190. https://doi.org/10.1377/hlthaff.2017.1104.

Dosaya, D., Shukla, T., \& Nirban, V. S. (2020). Transformation of Academic Ecology through Information Communication Technology adoption. International Journal of Information and Education Technology, 10(5), 372-377. https://doi.org/10.18178/ijiet.2020.10.5.1392.

Dubé, A. K., \& Dubé, N. J. (2021). Policies to Guide the Adoption of Educational Games into Classrooms. Educational Technology Research and Development, 69(1), 167-171. https://doi.org/10.1007/s11423-020-09835-9.

Falloon, G. (2020). From Digital Literacy to Digital Competence: The Teacher Digital Competency (TDC) Framework. Educational Technology Research and Development, 68(5), 2449-2472. 
https://doi.org/10.1007/s11423-020-09767-4.

Friedrichsen, D. M., Smith, C., \& Koretsky, M. D. (2017). Propagation from the Start: The Spread of a Concept-Based Instructional Tool. Educational Technology Research and Development, 65(1), 177202. https://doi.org/10.1007/s11423-016-9473-2.

Gde, I. W., Darma, Y., Bagus, I., Astika, P., Rm, M., \& Bambang, H. (2018). The Effect of Internal Control System , Tri Hita Karana Culture and Good Governance on Government Performance. Ijsbar, 42(3), 26-37.

Gogus, A. (2021). Shifting to Digital: Adoption and Diffusion. Educational Technology Research and Development, 69(1), 11-16. https://doi.org/10.1007/s11423-020-09862-6.

Grigoropoulos, J. E. (2019). The Role of Ethics in 21st Century Organization. International Journal of Progressive Education, 15(2), 167-175. https://doi.org/10.29329/ijpe.2019.189.12.

Grönlund, C. F., Söderberg, A., Dahlqvist, V., Sandlund, M., \& Zingmark, K. (2019). Communicative and Organizational Aspects of Clinical Ethics Support. Journal of Interprofessional Care, 33(6), 724733. https://doi.org/10.1080/13561820.2018.1551862.

Hao, H., \& Padman, R. (2018). An Empirical Study of Opinion Leader Effects on Mobile Technology Implementation by Physicians in an American Community Health System. Health Informatics Journal, 24(3), 323-333. https://doi.org/10.1177/1460458216675499.

Howard, S. K., Schrum, L., Voogt, J., \& Sligte, H. (2021). Designing Research to Inform Sustainability and Scalability of Digital Technology Innovations. Educational Technology Research and Development, 69(4), 2309-2329. https: //doi.org/10.1007/s11423-020-09913-y.

Huang, F., Sánchez-Prieto, J. C., Teo, T., García-Peñalvo, F. J., Olmos-Migueláñez, S., \& Zhao, C. (2021). A ross-Cultural Study on the Influence of Cultural Values and Teacher Beliefs on University Teachers' Information and Communications Technology Acceptance. Educational Technology Research and Development, 69(2), 1271-1297. https://doi.org/10.1007/s11423-021-09941-2.

Hyman, M. R., \& Sierra, J. J. (2016). Open-Versus Close-Ended Survey Questions. September 2015.

Ilomäki, L., \& Lakkala, M. (2018). Digital Technology and Practices for School Improvement: Innovative Digital School Model. Research and Practice in Technology Enhanced Learning, 13(1). https://doi.org/10.1186/s41039-018-0094-8.

Kintu, M. J., Zhu, C., \& Kagambe, E. (2017). Blended Learning Effectiveness: The Relationship Between Student Characteristics, Design Features, and Outcomes. International Journal of Educational, 14(7), 1-20. https://doi.org/10.1186/s41239-017-0043-4.

Kopcha, T. J., Neumann, K. L., Ottenbreit-Leftwich, A., \& Pitman, E. (2020). Process Over Product: The Next Evolution of Our Quest for Technology Integration. Educational Technology Research and Development, 68(2), 729-749. https://doi.org/10.1007/s11423-020-09735-y.

Kumar, M., Singh, K., \& Tewari, D. (2018). Workplace Conflict Resolution through Emotional Intelligence (EI). 1ST PAN IIT International Management Conference, 2018, December, 1-15.

Kusumayani, M. (2019). Pengaruh Model Pembelajaran Kooperatif Talking Stick Bermuatan Tri Hita Karana terhadap Kompetensi IPA Siswa IV SD. Pendidikan Multikultural Indonesia, 2. https://doi.org/10.23887/jpmu.v2i2.20805.

Loeb, S., Dynarski, S., Mcfarland, D., Morris, P., Reardon, S., \& Reber, S. (2017). Descriptive Analysis in Education: A Guide for Researchers. U.S.Department of Education, Institute of Education Science, National Center for Education and Evaluation, and Regional Assistance.

Mardiana, H. (2020). Lecturers' Adaptability To Technological Change and Its Impact on the Teaching Process. JPI, 9(2). https://doi.org/10.23887/jpi-undiksha.v9i2.24595.

Mehta, A., Morris, N. P., Swinnerton, B., \& Homer, M. (2019). The Influence of Values on E-learning Adoption. Computers and Education, 141(July). https://doi.org/10.1016/j.compedu.2019.103617.

Men, L. R. (2015). The Role of Ethical Leadership in Internal Communication. Public Relations, 9(May), 122.

Metwally, D., Ruiz-Palomino, P., Metwally, M., \& Gartzia, L. (2019). How Ethical Leadership Shapes Employees' Readiness to Change: The Mediating Role of an Organizational Culture of Effectiveness. Frontiers in Psychology, 10(November), https: //doi.org/10.3389/fpsyg.2019.02493.

Morrison, J. R., Ross, S. M., \& Cheung, A. C. K. (2019). From the Market to the Classroom: How Ed-Tech Products are Procured by School Districts Interacting with Vendors. In Educational Technology Research and Development (Vol. 67, Issue 2). Springer US. https://doi.org/10.1007/s11423-01909649-4.

Nugroho, A., Ilmiani, D., \& Rekha, A. (2021). EFL Teachers' Challenges and Insights of Online Teaching amidst Global Pandemic. Metathesis: Journal of English Language, Literature, and Teaching, 4(3), 277. https://doi.org/10.31002/metathesis.v4i3.3195. 
Nuswowati, M., Susilaningsih, E., Ramlawati, \& Kadarwati, S. (2017). Implementation of Problem-Based Learning with Green Chemistry Vision to Improve Creative Thinking Skill and Students' Creative Actions. Jurnal Pendidikan IPA Indonesia, 6(2), 221-228. https://doi.org/10.15294/jpii.v6i2.9467.

Pandis, N. (2014). Cross-Sectional Studies. American Journal of Orthodontics and Dentofacial Orthopedics, 146(1), 127-129. https://doi.org/10.1016/j.ajodo.2014.05.005.

Qureshi, M. I., Khan, N., Raza, H., Imran, A., \& Ismail, F. (2021). Digital Technologies in Education 4.0. Does it Enhance the Effectiveness of Learning? A Systematic Literature Review. International Journal of $\begin{array}{llll}\text { Interactive } \quad \text { Mobile } & \text { Technologies }\end{array}$ https://doi.org/10.3991/ijim.v15i04.20291.

Ross, S. M. (2020). Technology Infusion in K-12 Classrooms: A Retrospective Look at Three Decades of Challenges and Advancements in Research and Practice. Educational Technology Research and Development, 68(5), 2003-2020. https://doi.org/10.1007/s11423-020-09756-7.

Sailer, M., Murböck, J., \& Fischer, F. (2021). Digital Learning in Schools: What Does It Take Beyond Digital Technology? Teaching and Teacher Education, 103. https://doi.org/10.1016/j.tate.2021.103346.

Sedana Suci, I. G., Sonhadji, A., Imron, A., \& Arifin, I. (2018). Organizational Harmony in Hindu Higher Educatiob Institution Based on Tri Hita Karana Culture. Vidyottama Sanatana: International Journal of Hindu Science and Religious Studies, 2(1), 49. https://doi.org/10.25078/ijhsrs.v2i1.526.

Sharma, L., \& Srivastava, M. (2020). Teachers' Motivation to Adopt Technology in Higher Education. Journal of Applied Research in Higher Education, 12(4), 673-692. https://doi.org/10.1108/JARHE07-2018-0156.

Sharma, P. (2019). Digital Revolution of Education 4.0. International Journal of Engineering and Advanced Technology, 9(2), 3558-3564. https://doi.org/10.35940/ijeat.a1293.129219.

Smith, R. A., Kim, Y., Zhu, X., Doudou, D. T., Sternberg, E. D., \& Thomas, M. B. (2018). Integrating Models of Diffusion and Behavior to Predict Innovation Adoption, Maintenance, and Social Diffusion. Journal of Health Communication, 23(3), 264-271. https://doi.org/10.1080/10810730.2018.1434259.

Suarniati, I. G. A. \& E. al. (2019). Reflection of Tri Hita Karana Philosophy as A Local Wisdom of Bali Communities in Responding to Social Conflict in The Global Reform Era. International Journal of Sosiological Jurisprudence, 2(2), 127-133.

Sukarma, I. W. (2016). Tri Hita Karana: Theoretical Basic of Moral Hindu. International Journal of Linguistics, Literature and Culture, 2(3), 84. https://doi.org/10.21744/ijllc.v2i3.230.

Teräs, M., Suoranta, J., Teräs, H., \& Curcher, M. (2020). Post-Covid-19 Education and Education Technology 'Solutionism': a Seller's Market. Postdigital Science and Education, 2(3), 863-878. https://doi.org/10.1007/s42438-020-00164-X.

Tondeur, J., Petko, D., Christensen, R., Drossel, K., Starkey, L., Knezek, G., \& Schmidt-Crawford, D. A. (2021). Quality Criteria for Conceptual Technology Integration Models in Education: Bridging Research and Practice. Educational Technology Research and Development, 69(4), 2187-2208. https://doi.org/10.1007/s11423-020-09911-0.

Udemezue, J. C. (2018). Diffusion Network, Oppinion Leaders and Flow of Ideas. International Journal of Network and Communication Research, 5(1), 11-18.

Wang, X., \& Cheng, Z. (2020). Cross-Sectional Studies: Strengths, Weaknesses, and Recommendations. Chest, 158(1), S65-S71. https://doi.org/10.1016/j.chest.2020.03.012.

Weda, I. W., Putra, G., Parmiti, D. P., Suwatra, I. I. W., Guru, P., \& Dasar, S. (2016). Pengaruh Model Pembelajaran Savi Bermuatan Tri Hita Karana terhadap Hasil Belajar IPA Siswa Kelas IV. Mimbar PGSD Undiksha, 4(1). https://doi.org/10.23887/jjpgsd.v4i1.7166.

Weigel, F. K., Hazen, B. T., Cegielski, C. G., \& Hall, D. J. (2014). Diffusion of Innovations and the Theory of Planned Behavior in Information Systems Research: A Metaanalysis. Communications of the Association for Information Systems, 34(1), 619-636. https://doi.org/10.17705/1cais.03431.

Winter, E., Costello, A., O'Brien, M., \& Hickey, G. (2021). Teachers' Use of Technology and the Impact of $\begin{array}{llll}\text { Covid-19. Irish Sducational } & \text { Studies, }\end{array}$ https: //doi.org/10.1080/03323315.2021.1916559.

Yunita, N. K. D., \& Tristiantari, N. K. D. (2019). Pengaruh Model Pembelajaran Kooperatif Tipe TGT Berbasis Kearifan Lokal Tri Hita Karana terhadap Hasil Belajar. Jurnal Pendidikan Multikultural Indonesia, 1(2), 96. https://doi.org/10.23887/jpmu.v1i2.20778. 